\author{
Ю.Ф. Кучеренко ${ }^{1}$, О.В. Александров ${ }^{1}$, А.М. Носик ${ }^{2}$, С.В. Шубін ${ }^{1}$ \\ ${ }^{1}$ Харківський національний університет Повітряних Сил ім. І. Кожедуба, Харків \\ ${ }^{2}$ Національний технічний університет “Харківський політехнічний інститут”, Харків
}

\title{
МЕТОДОЛОГІЧНІ АСПЕКТИ ЩОДО ВИБОРУ МЕТОДУ ОЦІНКИ ЕФЕКТИВНОСТІ АВТОМАТИЗОВАНИХ СИСТЕМ ВІЙСЬКОВОГО ПРИЗНАЧЕННЯ ПРИ ЇХ ЗНАХОДЖЕННІ НА ВІДПОВІДНИХ СТАДІЯХ ЖИТТЄВОГО ЦИКЛУ
}

\begin{abstract}
У статті показане зростання ваги застосування автоматизованих систем військового призначення при веденні сучасних воєнних конфліктів збройними силами, щчо направлене на отримання інформаційної переваги над противником за рахунок використання можливостей єдиного командно-інформаційного простору всіма його користувачами, починаючи від командування і органів управління усіх рівнів та закінчуючи окремими екіпажами (вогневими і інформаційними засобами) й бійчями на полі бою. За таких умов, зараз в країні здійснюється розробка і впровадження різних автоматизованих систем військового призначення у Збройних Силах Украйни, які за своїми ознаками відносяться до складних організаційно-технічних та розподілених систем. Розкриті методологічні питання щэодо застосування того чи іншого варіанту здійснення оцінки їх ефективності за рахунок вибору певних шляхів оцінки з урахуванням знаходження даних систем на відповідних стадіях їх життєвого циклу. Показана необхідність здійснення оцінки ефективності систем за основними властивостями з метою здійснення порівняння можливостей між собою для визначення необхідних заходів, які направлені на підвищення науково-технічного рівня при розробиі або здійснення органами управління поточної оцінки ефективності функціонування у стислі терміни з метою прийняття рішення посадовими особами щодо визначення напрямів покращення функціонування та визначення якості прочесу управління силами та засобами в операчіях. Даний матеріал доцільно використовувати органам управління при здійсненні поточної оцінки ефективності функціонування автоматизованих систем військового призначення, для виконання необхідних заходів щуодо покращення їх надійності функціонування та при плануванні застосування відповідних сил та засобів в операціях або науковиям для здійснення порівняння різних систем між собою за основними властивостями при розробиі, впровадженні та під час здійснення експлуатаиії з метою встановлення відповідного науково-технічного рівня.
\end{abstract}

Ключові слова: автоматизована система військового призначення, бойові дї, властивість, ефективність, життєвий ичикл, мережецентрична війна, методологія, міжвидове угруповання, оцінка, показник, характеристика, функціонування.

\section{Вступ}

Постановка проблеми. На теперішній час, при веденні сучасних війн (збройних конфліктів) відбувається широкомасштабне застосування різних інформаційних засобів і розвідувально-ударних комплексів, а також автоматизованих систем військового призначення (АСВП), з метою підвищення ефективності управління міжвидовими угрупованнями (МУ) військ та їх бойовими засобами, а також забезпечення завоювання інформаційної переваги над противником. Війська, які управляються за допомогою АСВП, будуть мати більшу бойову ефективність за рахунок синхронізації своїх дій та максимальної адаптації їх під зміну обстановки в ході ведення бойових дій ніж ті, які не мають їі, хоча мають навіть і більший бойовий потенціал. Це свідчить про те, що настала епоха ведення мережецентричних війн (МЦВ), однією з головних ознак яких є жорстке протиборство різних АСВП між собою в єдиному командно-інформаційному просторі (СКІП). Вико- ристання командирами та органами управління широких можливостей ЄКІП дає їм можливість, географічно знаходячись на різних ділянках (в зонах відповідальності), через єдине представлення інформаційної моделі зміни динаміки бойових дій досягати високого рівня сумісності та взаємодії зусиль своїх підрозділів, які виконують завдання за єдиним замислом. Дані обставини вимагають здійснення розробки та впровадження у діяльність збройних сил низки різноманітних АСВП (розвідувальних систем, аналітичних систем, систем бойового управління частинами (підрозділами) різних видів і родів військ та їх бойовими засобами, систем обміну даними та зв'язку, систем забезпечення бойових дій (інформаційного, геодезичного, навігаційного, метеорологічного). При розробці, впровадженні та експлуатації АСВП керівний склад (органи управління), що планує іï застосування, технічний, що здійснює іiі експлуатацію або науковці, які здійснюють виконання заходів 3 військово-технічного су- 
проводження повинні знати - наскільки ефективна система, яка проектується (досліджується), впроваджується чи застосовується. Тому дуже часто на різних стадіях життєвого циклу АСВП постає питання:

1) як порівняти різні системи між собою, щоб оцінити, яка 3 них краще;

2) за якими показниками чи характеристиками їх треба оцінювати;

3) яке прийняти рішення за результатами їх застосування;

4) які з них ефективніші і на скільки.

Складність визначення ефективності АСВП полягає в тому, що вони відносяться до складних та територіально розподілених організаційно-технічних систем, які автоматизують складні процеси управління військами. Процес їх функціонування характеризується різноманітними просторовими, часовими, імовірнісними та іншими показниками, які носять складний характер і змінюються під впливом дії зовнішніх та внутрішніх факторів.

Тому надання деяких методологічних пояснень 3 вибору певного методу щодо здійснення оцінки ефективності АСВП при знаходженні ії на відповідній стадії життєвого циклу має актуальне значення як при бойовому застосуванні, для оцінки ії ефективності, так і при розробці перспективної АСВП при визначенні необхідного іiї науково-технічного рівня (НТР), для оцінки різних варіантів ії створення або порівнянні між собою різних АСВП.

Аналіз останніх досліджень і публікацій. В джерелах [1-23] розглядаються питання щодо ведення сучасних війн та управління військами в них [1-6], створення та розвитку різних АСВП [7-17], оцінки ефективності та шляхів розвитку різних систем [18-23]. Але вирішенню питань щодо вибору певного методу (шляху) оцінки ефективності АСВП 3 врахуванням знаходження іiі на відповідній стадії свого життєвого циклу, з методологічних позицій в них уваги не приділялось.

Головна мета статті полягає у визначенні методів оцінки ефективності АСВП в залежності від знаходження її на відповідній стадії життєвого циклу.

\section{Виклад основного матеріалу}

Наведемо деякі базові положення, які стосуються АСВП, щоб краще зрозуміти складність процесу оцінки їх ефективності. 3 методологічної точки зору при знаходженні АСВП у відповідний стадії іiі життєвого циклу на неї впливають певні зовнішні фактори. Під зовнішніми факторами впливу на АСВП, що створюються (модернізуються) або експлуатується, будемо розуміти такі фактори (об'єкти) зовнішнього середовища, які не є іiі внутрішніми елементами, але впливають на функціонування АСВП та іiі властивості (показники) і визначають загальносистемні вимоги (оперативно-стратегічні (оперативно-тактичні) та системотехнічні), що формують обрис конкретної АСВП (мету, призначення, структуру, завдання та інше) та впливають на визначення необхідного варіанту іiі створення з відповідним НТР, який вона повинна мати, щоб задовольнити загальним вимогам з реалізації процесу автоматизованого управління військами та бойовими засобами при іiі функціонуванні протягом певного терміну експлуатації.

Під внутрішніми факторами впливу на процес функціонування АСВП будемо розуміти фактори морального та фізичного старіння складових основ (елементів), а саме:

1) організаційної (невідповідність іiі організаційної структури - організаційній структурі військ, що нею керуються);

2) функціональної (невідповідність ii функціональних задач - задачам щодо автоматизованого управління військами та засобами в сучасних умовах ведення бойових дій);

3) матеріально-технічної (невідповідність характеристик іiі елементів (комплексів засобів автоматизації, засобів зв'язку та обміну даними, засобів обробки, зберігання, відображення інформації) сучасним вимогам щодо дії з інформацією (прийому, передачі, аналізу, переробці та таке інше).

За своєю сукупністю дії внутрішніх факторів визначають поточну відповідність даної АСВП загальним вимогам (які були визначені на основі ретельного аналізу зовнішніх факторів впливу на стадії їх проектування) і характеризують НТР.

НТР АСВП характеризує відповідну ступінь технічного вдосконалення, що відповідає вимогам зовнішніх та внутрішніх факторів впливу у визначеній перспективі, з врахуванням впровадження передових досягнень науки та техніки, що були реалізовані при її створенні, у порівнянні з іншими аналогічними системами.

Під життєвим циклом АСВП будемо представляти собою процес послідовного знаходження іiі у відповідних станах, що змінюються, у відповідності до стадій життєвого циклу, а саме: передпроектної стадії (ППС); стадії розробки (СР); стадії впровадження (СB), стадії експлуатації (CE) та утилізації (СУ).

На рис. 1 представлені стадії життєвого циклу АСВП, які послідовно поєднані між собою за їх виконанням і характеризується реалізацією виконання конкретних завдань та заходів, які необхідно виконати на кожній стадії, щоб реалізувати конкретний іiі стан (проектної моделі (ПМ), дослідного зразка (ДЗ), прийняття на озброєння (ПО), застосування зразка озброєння (33О) з відповідним НТР та утилізації зразка (УЗ). На рис. 1 НТР АСВП представлений у вигляді кривої, де спочатку на ППС відбува- 
ється його зріст бо поступово формується обрис системи (ПМ), визначаються значення ії показників i характеристик, визначається необхідний ii НТР, який потрібно мати на перспективу, по відношенню до обраного прототипу (НТР прототипу прийнято за одиницю - пряма пунктирна лінія на графіку). Потім на СР (АСВП перебуває у стані Д3) та СВ (АСВП перебуває у стані ПО) здійснюється підтвердження НТР, що був спланований на ППС - відбувається невелике зростання НТР у порівнянні з запланованим (запланований НТР - 1,25) за рахунок застосування новітніх технологій, які були впроваджені під час розробки ДЗ. На СЕ (АСВП перебуває у стані 33О) поступово здійснюється зниження іiі НТР завдяки процесам морального та фізичного старіння i після досягнення граничного значення НТР приймається рішення про зняття іiї $з$ експлуатації та утилізацію.

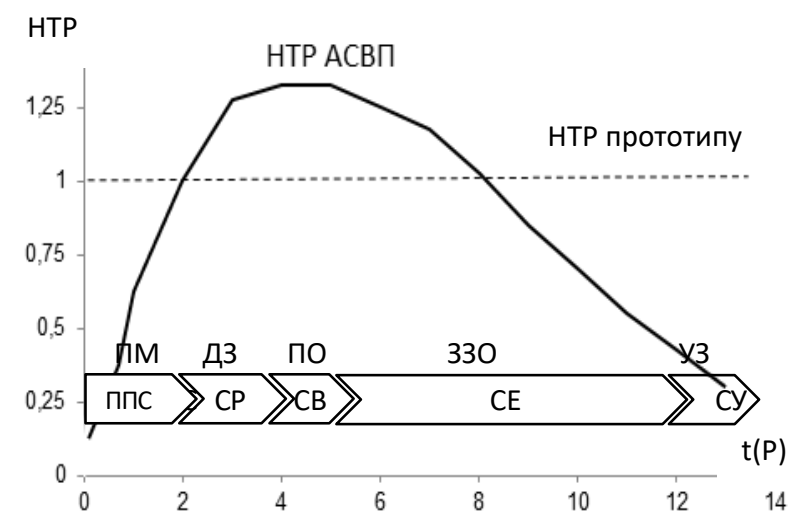

Рис. 1. Графік залежності НТР АСВП від знаходження іiї у станах та стадіях життєвого циклу Джерело: розроблено авторами.

Кожна АСВП характеризується своїми властивостями (боєготовністю, оперативністю, безперервністю, стійкістю, скритністю), які мають комплексний характер, бо складаються з багатої кількості показників, що їх визначають.

В свою чергу, показники теж визначаються багатьма характеристиками. Показники (характеристики) АСВП характеризуються багатьма різноманітними просторовими, часовими та імовірнісними характеристиками, що визначаються зовнішніми та внутрішніми факторами впливу на неї. Таким чином, всі вони за своєю сукупністю складають ієрархічну, розвинену (розгалужену) структуру системи властивостей та показників (характеристик) даних систем.

Взаємопов'язана система властивостей і показників (характеристик) з усіх сторін характеризує певну АСВП, з відповідним НТР.

Взаємовплив властивостей (показників, характеристик) одна на одну в динамічному процесі управління військами і бойовими засобами, що здійснюється за допомогою АСВП, визначає складність ïх оцінки, а тому в математичному сенсі їх взаємозалежність визначається дуже складними математичними виразами і не завжди їх можливо об'єднати для визначення єдиного інтегрального показника ефективності функціонування АСВП. Чим більше розглядається властивостей АСВП при порівнянні, тим важче буде об'єднати в єдиний інтегральний показник, тому в більшості випадків при оцінки ефективності необхідно застосовувати принцип декомпозиції.

При знаходженні АСВП на ППС іiі життєвого циклу (у стані ПМ), коли формується обрис системи та визначається потрібний іiі НТР, для порівняння даної системи (проектної моделі) з існуючим прототипом необхідно здійснити визначення значень основних властивостей (показників та характеристик) проектної моделі та порівняти їх з відомими значеннями властивостей обраного прототипу, щоб у подальшому встановити: наскільки АСВП, що розроблюється, краще або гірше за конкретними властивостями (показниками, характеристиками) і в цілому визначити наскільки вона ефективніше.

Тоді, для оцінки ефективності АСВП, що знаходиться на ППС іiі життєвого циклу, доцільним буде використовувати метод загальної кількісної оцінки іï ефективності, який враховує найбільшу кількість визначених властивостей (показників та характеристик) системи з метою точнішого встановлення ефективності кожної властивості (показника) i загальної ефективності АСВП відносно обраного прототипу, наступним чином (рис. 2).

1. Спочатку необхідно, застосовуючи принцип декомпозиції, розбити визначену систему властивостей (показників і характеристик) на певні підсистеми за кількістю властивостей АСВП, що досліджуються (боєготовністю, оперативністю, безперервністю, стійкістю, скритністю).

2. Потім поступово здійснити оцінку кожної властивості, починаючи з оцінки самого нижнього рівня ієрархії, де представлені прості характеристики, потім більш складні і далі показники даної властивості. Після оцінки кожного показника, що характеризує дану властивість, з врахуванням ваги впливу кожного показника на неї, здійснюється оцінка ефективності властивості АСВП.

3. Після встановлення ефективності кожної властивості, приймаючи до уваги їх рівнозначний вплив на загальну ефективність АСВП, необхідно визначити іii за інтегральною оцінкою оцінених іiі властивостей, застосовуючи при цьому відповідні правила (наприклад, як середнє арифметичне значення ефективності властивостей). 
Застосовуючи принцип декомпозиції система властивостей (показників) АСВП розбивається на підсистеми за кількістю властивостей, що досліджуються

Визначаються показники та характеристики кожної властивості та здійснюється їх оцінка ефективності кожної функціональної підсистеми АСВПі

Визначається ефективність АСВП за інтегральною оцінкою ефективності кожної властивості

Рис. 2. Структурна схема методу загальної кількісної оцінки ефективності АСВП Джерело: розроблено авторами.

Метод загальної кількісної оцінки ефективності АСВП доцільно використовувати на СР (де система знаходиться у стані Д3 і потрібно здійснювати оцінку проектних рішень, що розроблені) і на СВ (де приймається рішення про можливість застосування дослідного зразка за призначенням та його приймання на озброєння) для здійснення кількісної оцінки показників (характеристик), що реалізовані і визначення досягнутого НТР системи.

При знаходженні АСВП на СЕ впродовж певного часу, буде відбуватись зниження іiї НТР внаслідок дії процесу поступового іiі морального та фізичного старіння, що відбувається під впливом дії внутрішніх факторів. Дані обставини вимагають від осіб експлуатантів АСВП здійснювати контроль за якістю функціонування як всієї системи, так і іiі складових основ, а також здійснювати загальну оцінку їх ефективності. Це необхідно робити з метою розробки пропозицій щодо проведення певних дій (змін) у їх організаційній, функціональній та матеріально-технічній складових, для забезпечення відповідності їх поточного НТР існуючим вимогам щодо здійснення автоматизованого управління силами та засобами.

Визначення ефективності функціонування АСВП експлуатантами, які мають менший рівень науково-дослідної підготовки, ніж науковці науково-дослідних установ замовника та небагато часу на проведення відповідних розрахунків, повинно здійснюватись з застосуванням менш складних методів їх визначення.

Тому, для оцінки ефективності АСВП, що знаходиться на $\mathrm{CE}$, доцільним буде використовувати метод якісної оцінки ефективності системи, який визначає загальну її ефективність, яка представлена комплексним показником, що характеризується основними показниками іiі складових основ. Тобто показниками ефективності організаційної (характеризуються рівнем укомплектованості та підготовки органів управління і технічного персоналу), функціональної (характеризуються відсотком завдань, що вирішуються автоматизованим способом, точністю і часом їх вирішення) та матеріально-технічної іiї основи (ступенем наявності автоматизованих пунктів управління (АПУ), ступенем їх захищеності, рівнем оснащення АПУ КЗА та засобами зВ'язку (33), технічною надійністю КЗА та 33).

Тоді, для якісної оцінки ефективності АСВП, що знаходиться на СЕ, експлуатантами даної системи необхідно виконати наступні дії щодо ії визначення, згідно схеми, що наведена на рис. 3 .

1. Спочатку необхідно застосовуючи принцип декомпозиції розбити АСВП за ії трьома основними складовими (організаційною, функціональною та матеріально-технічною) і визначити для кожної 3 них відповідні показники і характеристики, що їх характеризують, та здійснити розрахунки поточних їх значень

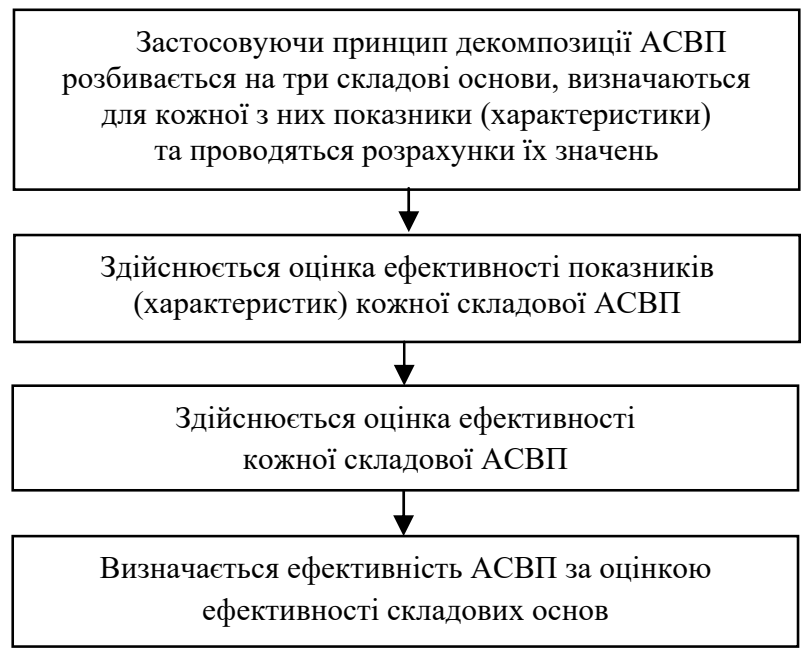

Рис. 3. Структурна схема методу якісної оцінки ефективності АСВП на основі оцінки складових основ

Джерело: розроблено авторами.

2. Потім треба здійснити оцінку ефективності показників та характеристик кожної складової основи АСВП (здійснюється розрахунок у відсотковому відношенні поточного значення певної характеристики (показника) відповідно до заданого іiї значення або до значення відповідної характеристики при ідеальному функціонуванні АСВП), з встановленням їм відповідної оцінки за школою (“відмінно”, “добре”, “задовільно”, “незадовільно”), які обираються за оціночними інтервалами (інтервали встановлюються на основі застосування експертного методу).

3. Після чого здійснюється оцінка ефективності кожної складової основи АСВП, починаючі з самого нижнього ієрархічного рівня їх характеристик, послідовно доходячи до показників, що їх визначають, 
за обраним правилом оцінки - доцільно застосовувати правило “вузького місця” (проводити оцінку за одним із найгірших значень оцінених характеристик (або показників) на кожному рівні ієрархіï).

4. Після встановлення ефективності кожної 3 складових основ необхідно визначити ії загальну ефективність за інтегральною оцінкою ефективності оцінених іiі складових основ, тобто за мінімальним значенням оціненого стану функціонування організаційної, функціональної або матеріально-технічної складової АСВП на поточний момент часу (за правилом “вузького місця”).

При застосуванні АСВП в особливих умовах (при веденні бойових дій) на СЕ керівному складу (органам управління) необхідно здійснювати поточну оцінку ефективності іiі функціонування у на коротший час, бо це необхідно робити паралельно вподовж часу здійснення циклів управління підпорядкованими військами та засобами при виконанні ними бойових завдань. При веденні сучасних бойових дій, в яких одним з головних завдань $є$ порушення функціонування системи управління військами та засобами противника, необхідно безперервно проводити заходи (дії) щодо захоплення та утримання інформаційного панування над ним, 3 обов'язковим відслідковуванням поточного стану АСВП (після кожного факту застосування сил і засобів противника) за рахунок здійснення оцінки ефективності іiі функціонування, з метою подальшого прогнозування якості виконання підпорядкованими військами бойових завдань та вибору шляхів щодо покращення iĭ функціонування.

Оскільки загальна ефективність функціонування АСВП залежить від своєчасності та якості виконання нею усіх оперативних та інформаційнорозрахункових задач і математичних моделей, що служить основою для забезпечення підвищення ефективності процесу управління військами при виконанні ними бойових завдань, то для проведення поточної оцінки іiї ефективності органами управлін-

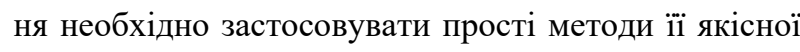
оцінки, що виконуються у стислі терміни.

Тоді, для поточної оцінки ефективності АСВП, під час іiї застосування при веденні бойових дій органами управління необхідно застосовувати метод якісної оцінки іiї ефективності, що враховує вагомість, своєчасність та якість виконання нею завдань за призначенням, за наступною схемою рис. 4.

1. Спочатку необхідно застосовуючи принцип декомпозиції розбити АСВП за функціональними ознаками на відповідні функціональні підсистеми (кожна підсистема характеризується відповідним набором визначених функціональних завдань, які складаються з визначеної сукупності спеціальних взаємопов'язаних оперативних, інформаційних, розрахункових, аналітичних задач і моделей). Для кож- них з них необхідно визначити відповідні показники, що їх характеризують (час їх вирішення, якість їх вирішення) та встановити відповідну їх вагомість, що можливо визначити експертним шляхом, застосовуючи метод експертних оцінок.

2. Після чого необхідно здійснити оцінку ефективності кожної функціональної підсистеми за сукупністю виконання нею своїх функціональних завдань 3 врахуванням їх вагомості, якості і своєчасності вирішення.

3. Далі, за результатом оцінки ефективності кожної функціональної підсистеми визначити загальну ефективність функціонування АСВП, як середнє арифметичне значення ефективності функціонування підсистем, що іiї утворюють (за умов що вони рівнозначні за своїм впливом на функціонування AСВП).

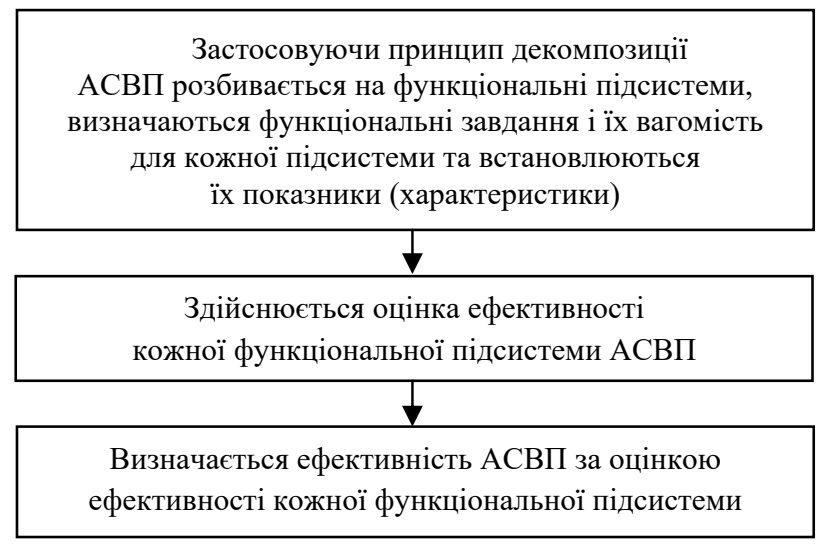

Рис. 4. Структурна схема методу якісної оцінки ефективності АСВП на основі оцінки функціональних підсистем Джерело: розроблено авторами.

Аналіз вибору методів оцінки ефективності АСВП в залежності від іiі перебування на відповідній стадії життєвого циклу показує наступне.

Застосування методу загальної кількісної оцінки іiі ефективності доцільно проводити на ППС, СР і $\mathrm{CB}$, бо він потребує наявності високої кваліфікації у виконавців (науковців науково-дослідних установ замовника), що всебічно досліджують систему, їх значної кількості та значного часу на його застосування. Перевагою його застосування є те, що він дає можливість здійснити кількісну оцінку обраних властивостей (показників та характеристик), що дозволяє зробити обгрунтований і точний висновок про якість АСВП та її НТР.

Метод якісної оцінки ефективності АСВП на основі оцінки складових основ доцільно використовувати при знаходженні їі на СЕ. Він не такий складний, як попередній метод, потребує середньої кваліфікації виконавців. Дозволяє здійснити якісну оцінку ефективності як складових основ, так і всієї 
АСВП за відносно невеликий час. Знаючи стан складових основ АСВП можливо здійснювати виконання певних заходів щодо їх покращення, тим самим підвищити якість функціонування АСВП під час експлуатації. До недоліку можливо віднести те, що за допомогою нього можливо здійснити приблизну оцінку ефективності АСВП.

Застосування методу якісної оцінки ефективності АСВП на основі оцінки виконання нею завдань за призначенням не потребує особливої кваліфікації виконавців. Він дозволяє керівному складу (органам управління) за досить короткий час в умовах ведення бойових дій здійснити якісну поточну оцінку ефективності АСВП, застосовуючи при цьому прості розрахунки. До його недоліку слід віднести те, що при його застосуванні можливо отримати тільки приблизну оцінку ефективності АСВП за результатами вирішення завдань за призначенням.

\section{Висновок}

Автоматизовані системи військового призначення відносяться до складних організаційнотехнічних та розподілених систем, які характеризуються ієрархічною, розгалуженою системою взаємопов'язаних властивостей та показників. Тому, визначення ефективності АСВП при перебуванні на відповідних стадіях життєвого циклу представляє собою складне завдання. Представлені методологічні аспекти щодо вибору методів оцінки ефективності АСВП в залежності від знаходження їх на відповідних стадіях життєвого циклу нададуть можливість науковцям науково-дослідних організацій замовника, експлуатантам та органам управління застосовувати необхідні підходи щодо визначення їх ефективності як при їх розробці, так і при їх експлуатації, в тому числі і при бойовому застосуванні.

\section{Список літератури}

1. Владимиров А.И. Основы общей теории войны: монография в 2-х частях / А.И. Владимиров. - М.: Синергия, 2013. - 832 с. (часть I), 976 с. (часть II).

2. Сидорин А.Н. Вооруженные силы США в ХХІ веке: Военно-теоретический труд / А.Н. Сидорин, В.М. Прищепов, В.П. Акуленко. - М.: Кучково поле, 2013. - 800 с.

3. Лященко В.П. Воздушно-космическая оборона государства: современные этапы и перспективы развития / В.П. Лященко. - М.: Экономика, 2015. - 366 с.

4. Савин Л.В. Сетецентрическая и сетевая война. Введение в концепцию / Л.В. Савин. - М.: Евразийское движение, 2011. -130 c.

5. Паршин С.А. Кибервойны - реальная угроза национальной безопасности? / С.А. Паршин, Ю.Е. Горбачев, Ю.А. Кожанов. - М.: КРАСАНД, 2011. - 96 с.

6. Информационные, специальные, воздушно-десантные и аэромобильные операции армий ведущих зарубежных государств / А.Н. Сидорин, И.А. Рябченко, В.П. Герасимов и др. - М.: Воениздат, 2011. - 344 с.

7. Основы теории применения управления в системах специального назначения / Ю.В. Бородакий, А.В. Боговик, В.И. Курносов и др.; под общ. ред. Ю.В. Бородакия, В.В. Масановца. - М.: Управление делами президента РФ, 2008. $400 \mathrm{c}$.

8. Управління проектами зі створення зразків озброєння та військової техніки в умовах прояву факторів невизначеності та ризику / Б.О. Демідов, О.Ф. Величко, Ю.Ф. Кучеренко, М.В. Куцак // Озброєння та військова техніка. - 2016. - № 2(10). - С. 15-19.

9. Искусственный интеллект и интеллектуальные системы управления / И.М. Макаров, В.М. Лохин, С.В. Манько, М.П. Романов. - М.: Наука, 2006. - 333 с.

10. Московитов Н. Перспективы создания глобальной информационной сети МО США / Н. Московитов, Г. Рыбаков // Зарубежное военное обозрение. - 2013. - № 7. - С. 8-19.

11. Демідов Б.О. Концептуальні положення щодо створення автоматизованої системи управління протиповітряною обороною держави / Б.О. Демідов, О.Ф. Величко, Ю.Ф. Кучеренко // Наука і оборона. - 2014. - № 3. - С. 51-56.

12. Ярош С.П. Теоретичні основи побудови та застосування розвідувально-управляючих інформаційних систем протиповітряної оборони / С.П. Ярош. - Х.: ХУПС, 2012. -512 с.

13. Ковалевський С.М. Пропозиції щодо створення скритого маловисотного радіолокаційного поля в умовах ведення сучасних мережецентричних та гібридних війн / С.М. Ковалевський, Г.В. Пєвцов, Г.В. Худов // Наука і техніка Повітряних Сил Збройних Сил України. - 2015. - № 1(18). - С. 77-81.

14. Васильев В.И. Интеллектуальные системы управления. Теория и практика / В.И. Васильев, Б.Г. Ильясов. - М.: Радиоэлектроника, 2009. - 392 с.

15. Куприянов А.И. Радиоэлектронные системы в информационном конфликте / А.И. Куприянов, А.В. Сахаров. М.: Вузовская книга, 2003. -528 с.

16. Худов Г.В. Методика синтезу раціональної структури підсистеми розвідки системи протиповітряної оборони 3 використанням генетичного алгоритму / Г.В. Худов, І.А. Таран // Наука і техніка Повітряних Сил Збройних Сил України. - 2016. - № 2(23). - С. 25-31.

17. Котенко И.В. Теория и практика построения автоматизированных систем информационной и вычислительной поддержки процессов планирование связи на основе новых информационных технологий / И.В. Котенко. - СПб.: ВАС, 1998. -404 c.

18. Архипова К.З. Повышение эффективности процессов технического контроля в несерийном производстве сло- 
жной технической продукции / К.З. Архипова, Н.А. Меняшева, Е.А. Шабанова // Методы менеджмента качества. - 2019. - № 4. - С. 50-55.

19. Кучеренко Ю.Ф. Методика оцінки загального стану автоматизованої системи військового призначення на основі визначення технічного стану комплексів засобів автоматизації, що ії складають / Ю.Ф. Кучеренко // Системи обробки інформації. - 2017. - № 3(149). - С. 118-120.

20. Ганношина I.M. Метод автоматизації процесу визначення маршруту судна при плануванні переходу / I.M. Ганношина, О.А. Дакі // Системи обробки інформації. - 2019. - № 2(157). - С. 84-89. https://doi.org/10.30748/soi.2019.157.11.

21. Jonathan Ch. Quality of service control in high-speed networks / Ch. Jonathan, G. Xiaolei. - New York: Wiley, 2002. $432 \mathrm{p}$.

22. Особливості автоматизації процесів вироблення рішень при оцінці повітряної обстановки на пунктах управління Повітряних Сил Збройних Сил України / Н.О. Королюк, А.В. Леонов, М.Р. Будков, Д.А. Литвин // Системи озброєння і військова техніка. - 2020. - № 1(61). - С. 106-112. https://doi.org/10.30748/soivt.2020.61.12.

23. Напрями удосконалення автоматизованих систем управління для артилерії Сухопутних військ Збройних Сил України / Л.С. Демидко, П.Є. Трофименко, Г.В. Сорокоумов, І.С. Луговський // Системи озброєння і військова техніка. 2018. - № 2(54). - C. 83-88. https://doi.org/10.30748/soivt.2018.54.11.

Надійшла до редколегії 10.03.2021

Схвалена до друку 13.04.2021

\section{Відомості про авторів:}

\section{Кучеренко Юрій Федорович}

кандидат технічних наук старший науковий співробітник провідний науковий співробітник Харківського національного університету Повітряних Сил ім. І. Кожедуба, Харків, Україна https://orcid.org/0000-0001-9937-371X

\section{Information about the authors:}

Yurii Kucherenko

Candidate of Technical Sciences

Senior Research

Lead Research

of Ivan Kozhedub Kharkiv National

Air Force University,

Kharkiv, Ukraine

https://orcid.org/0000-0001-9937-371X

\author{
Oleksandr Aleksandrov \\ Candidate of Technical Sciences \\ Senior Research \\ Head of Scientific Research Department \\ of Ivan Kozhedub Kharkiv National \\ Air Force University, \\ Kharkiv, Ukraine \\ https://orcid.org/0000-0001-6405-9456
}

\author{
Andrii Nosyk \\ Candidate of Technical Sciences \\ Senior Research \\ Senior Lecturer of National Technical University \\ "Kharkiv Polytechnic Institute", \\ Kharkiv, Ukraine \\ https://orcid.org/0000-0002-4171-1875
}

\author{
Evgen Shubin \\ Candidate of Technical Sciences \\ Senior Research \\ Senior Research Associate \\ of Ivan Kozhedub Kharkiv National \\ Air Force University, \\ Kharkiv, Ukraine \\ https://orcid.org/0000-0002-3411-8125
}

\section{МЕТОДОЛОГИЧЕСКИЕ АСПЕКТЫ ПО ВЫБОРУ МЕТОДА ОЦЕНКИ ЭФФЕКТИВНОСТИ АВТОМАТИЗИРОВАННЫХ СИСТЕМ ВОЕННОГО НАЗНАЧЕНИЯ ПРИ ИХ НАХОЖДЕНИИ НА СООТВЕТСТВУЮЩИХ СТАДИЯХ ЖИЗНЕННОГО ЦИКЛА}

Ю.Ф. Кучеренко, А.В. Александров, А.Н. Носик, Е.В. Шубин

В статье показано возрастание роли применения автоматизированных систем военного назначения при ведении современных конфликтов вооруженными силами, которое направлено на получение информационного преимущества над противником за счет использования возможностей единой командно-информационной среды всеми ее пользователями, начиная от командования и органов управления всех уровней и заканчивая отдельными экипажами (огневыми и 
информационными средствами) и солдатами на поле боя. При таких условиях, сейчас в стране осуществляется разработка и внедрение разных автоматизированных систем военного назначения в Вооруженных Силах Украины, которые по своим признакам относятся к сложным организачионно-техническим и распределенным системам. Раскрыты методологические вопросы по применению того или иного варианта осуществления оценки их эффективности за счет выбора некоторых путей их оценки с учетом нахождения данных систем на соответствующей стадии их жизненного иикла. Показана необходимость осуществления оценки эффективности по основным их особенностям с целью осуществления сравнения их возможностей между ними для определения необходимых мероприятий, которые направлены на повышение их научно-технического уровня при их разработке или осуществлении органами управления текущей оценки эффективности их функционирования в короткие сроки с целью принятия решения должностными лицами по определению направлений улучшения их функционирования и определения качества прочесса управления войсками и средствами в операции. Данный материал целесообразно использовать органам управления при осуществлении текущей оценки эффективности функиионирования автоматизированных систем военного назначения для выполнения необходимых мероприятий по улучшению надежности их функционирования при планировании применения соответствуюших сил и средств в операчии или учеными для осуществления сравнения разных систем между собой по основным их свойствам при их разработке и во время их эксплуатации с иелью определения соответствующего их научно-технического уровня.

Ключевые слова: автоматизированная система военного назначения, боевые действия, свойство, эффективность, жизненный ијикл, сетецентрическая война, методология, межвидовая группировка, оценка, показатель, характеристика, функиионирование.

\section{METHODOLOGICAL ASPECTS ON THE CHOICE OF A METHOD FOR ASSESSING THE EFFICIENCY OF AUTOMATED MILITARY CONTROL SYSTEMS WHEN THEY ARE AT THE RELEVANT STAGES OF THE LIFE CYCLE}

Yu. Kucherenko, O. Aleksandrov, A. Nosyk, E. Shubin

The article shows the increasing role of the use of automated military systems in the conduct of modern conflicts by the armed forces, which is aimed at gaining an information advantage over the enemy by using the capabilities of a single command and information environment by all its users, from command and control bodies of all levels to individual crews (fire and information means) and soldiers on the battlefield. Under such conditions, now the country is developing and implementing various automated military systems in the Armed Forces of Ukraine, which by their characteristics refer to complex organizational, technical and distributed systems. The methodological issues on the application of one or another option for assessing their effectiveness by choosing some ways of assessing them, taking into account the finding of these systems at the appropriate stage of their life cycle, are disclosed. It is shown that it is necessary to assess the effectiveness of their main features in order to compare their capabilities with each other to determine the necessary measures that are aimed at increasing their scientific and technical level in their development or implementation by the governing bodies of the current assessment of the effectiveness of their functioning in a short time in order to make a decision officials to determine the directions for improving their functioning and determine the quality of the process of command and control of troops and assets in an operation. It is advisable to use this material for control bodies in the implementation of the current assessment of the effectiveness of the functioning of automated military systems in order to take the necessary measures to improve the reliability of their functioning when planning the use of appropriate forces and means in an operation or by scientists to compare different systems with each other for their main properties in their development and during their operation in order to determine their appropriate scientific and technical level.

Keywords: automated system for military purposes, combat operations, property, efficiency, life cycle, network-centric warfare, methodology, interspecific grouping, assessment, indicator, characteristics, functioning. 